\title{
Effect of Games Including Physical Activity on Digital Game Addiction of 11-14 Age Group Middle-School Students
}

\author{
Zekihan hazar $^{1}$, Muhsin Hazar $^{2}$ \\ ${ }^{1}$ Niğde Ömer Halisdemir Universty School of Physical Education and Sports, Turkey \\ ${ }^{2}$ Gazi Universty Sport Science Faculty, Turkey \\ Correspondence: Zekihan hazar, Niğde Ömer Halisdemir Universty School of Physical Education and Sports, Turkey.
}

Received: September 26, 2018

Accepted: October 14, $2018 \quad$ Online Published: October 17, 2018

doi:10.11114/jets.v6i11.3645

URL: https://doi.org/10.11114/jets.v6i11.3645

\begin{abstract}
In this study, it was investigated that effect of games including physical activity on digital game addiction of 11-14 age group middle-school students. Along with the determination of digital game addiction, conducting applied experimental study is important regarding showing results of application with theoretical knowledge towards solving problem. Within this framework, it was thought that "games including physical activity" will be important tool for decreasing the level of digital game addiction. Experimental Design method was used in the study in which was adopted Quantitative Research model. When 11-14 age group students who addicted digital games consisted of the population of the study, the sample of the study consisted of 29 girls and 51 boys who have studied. In the study, personal information form and digital game addiction scale that was developed by the researcher were used as measurement tools. During data collection period, by accepting applied pre-test to students as criterion sample process, students who have high addiction level (total scale score is 49 and above) were detected and control $(n=40)$ and experimental $(n=40)$ groups were created with unbiased assignment method. After the 12-weeks period "games including physical activity" training, the data which was collected from the control and experimental groups by taking post-test data was evaluated with SPSS 20 packaged software. It was found that there was a significant difference between pre-test and post-test of both sub-dimensions and total addiction scores and post-test scores were lower than pre-test scores. It was shown that post-test addiction scores were significantly higher than pre-test addiction scores in control group. When investigating post-test addiction scores of control and experiment groups, it was shown that addiction level of experimental group significantly decrease comparing control group. It was determined that pre-test/post-test scores of experimental group students did not show significant differences in terms of gender, age, education level of mothers, education level of fathers, number of siblings. It was also found that pre-test/post-test addiction scores of experimental and control groups showed significant differences regarding playing digital game duration. When playing digital game duration decreased in experimental group, playing game duration increased in control group. Therefore, it was concluded that addiction levels of students who are digital game addict decreased because of interesting games including physical activity. As a result; physical moving games and sports can be said to be an important tool in dealing with digital game addiction. It can also be said that an important way to protect children from such addictions is to do sports.
\end{abstract}

Keywords: game, digital game, game addiction, addiction solution

\section{Introduction}

As the developing technology provides many practices in human life and human beings have become an undeniable fact that they shape many basic living areas from education to health, transportation communication and entertainment, the games which are one of these basic living spaces have taken the same from this change. The behavior of the game that started by mimicking some natural phenomena of mankind has gained a distinct dimension with imaginary games (digital games) played with special computer software and game tools today. It is also a fact known that this technology that develops brings along with the practices that it brings to human life, it has some negative consequences with it. One of the most important of these problems is technology addiction. One of the most prominent titles is the subject of computer addiction and "digital game addiction" which is evaluated under this title (Hazar \& Hazar).

The rapid rise of information technology has greatly accelerated the increase in users. Especially the majority of young people spend their time in front of computers (Yengin, 2010). With the years of the 2000s, computer games have begun 
to increase in influence in social life, becoming one of the most popular entertainment tools (Binark, Bayraktutan-Sütçü ve Fidaner).One of the innovations that the computer industry brings to the life of the child is the concept of "digital game" (Erboy \& Akar Vural). Digital games have been defined as computer games, video games, electronic games since the middle of the 1980s. Define computer games are widely used in Turkey (Binark \& Bayraktutan, 2008).

In the past, while games often interacted with friends in non-closed spaces (game parks, streets, etc.), nowadays with the development of technology, especially with computers and the internet, it is now started to play with people in virtual environment in closed and virtual environments (Horzum, Ayas and Cakir-Balta).In many of our experiences that have become virtual, our games have got their share (Kaya, 2013). On the other hand, in today's digital world, where the Internet and mobile technologies are particularly well-known, criticisms are being brought to the game from physical and social perspectives. Some of the most important criticisms of these kinds of games that have a very important problem like addiction are that these games have negative effects on the physical, mental and social development of children compared to traditional games (Torun, Akçay \& Çolaklar, 201).

People are worried that computer and video games (digital games) are good or bad for their children (Smith, 2004, p. Computer games can be both good and bad depending on the content of the game, when and how much it plays (Kars, $2010, \mathrm{p}$. When the area is examined in the literature, it is revealed that digital games have many negative effects on the players. Especially, the children who are in development period are exposed more easily to the negative effects of digital games in cognitive, emotional, social and physical terms and as a result; hyperactivity, learning disorders, psychomotor disorders in children, health problems due to lack of activity and movement, antisocial behaviors, and most importantly, digital game addiction, are neglecting everyday life tasks and responsibilities, aggressive behaviors, mechanization in the players, personality impairments, increase in negative emotions.(Horzum el al., 2008; Dolu el al., 2010; Şahin \& Tuğrul, 2012; Akçayır, 2013;;Arslan et al., 2014).

According to Griffiths and Meredith (2009), as a result of scientific research, it is seen that digital game addiction has many psychological and physiological effects on individuals. Gentile \& Anderson (2006) stated that there are many scientific studies of the harmful effects of digital games on children and that it may lead to negative psychological and social consequences such as aggressive thoughts, aggressive behaviors and social behavior decrease in short and long term, especially in violent digital games tend to. Lieberman et al. (2009) digital games; they can lead to negative consequences such as sending violence and fear, exhibiting emotional and aggressive behavior, spending a large part of the time with digital games rather than exploratory games, and being away from physical and social activities.

The most important concept that draws attention within the scope of all these discussions is the concept of "addiction". One of the most critical periods during developmental periods, 11-14 years of age, emerges as one of the periods in which the individual shows particular tendencies such as substance and behavior addiction. One of the most serious problems that digital gaming brings with excessive and uncontrolled is the "digital game addiction" problem, if the substance use habit is accompanied by a problem of addiction. The fact that today's adverse effects may be particularly adverse to the developing technology, and the fact that gaming devices can easily be provided to children in various ways (such as personal gaming devices or internet cafes) to play uncontrollably cause children to become addicted to digital gaming over time (Young, Ozturk, 2007; Tarhan \& Nurmedov, 2011; Ögel, 2012; Demirtaş \& Ferligül, 2014; Burak \&Ahmetoğlu, 2015).

However, the decline in the number of sports and moving games (traditional games) every day in children's lives is an important reason for digital game addiction. In order to cope with digital game addiction, it is considered that directing children to sports and moving games by offering alternative activity opportunities can be an effective method to solve this problem. In this context, it is aimed to give a new perspective to this study area by examining the effects of physical activity games on the level of digital game addiction by determining the level of digital game addiction of children in the 11-14 age group.

\section{Method}

Research was designed according to the quantitative research model and "classical experimental setup" was used as the experimental research design. In this study, the effect of physical activity games on the digital game addiction of 11-14 age group middle school students was examined using control group pre-test post-test experimental research design. Measurements were made before and after the experimental process in both groups.

In the experimental process; no changes were made to the students in the control group. For the students in the experimental group, a 12-week "physical activity game program" was prepared, which was applied two days a week on Mondays and Wednesdays (each application is at least 120 minutes). In the preparation of the content of the implemented program; field texts were examined and factors such as the age, gender, number of participants of the selected games were taken into consideration by taking opinions from field experts (Educational games). 


\subsection{Research Universe}

Depending on the purpose of the research, it is called the coined universe of all the individuals (units) that can be studied or generalized.Purposeful sampling is an appropriate sampling technique for individuals with specific, restrictive, and difficult individual characteristics. The aim here is to reach the individuals with the relevant characteristics (Erkuş, 2013, p.118).

In this context, the universe of research is composed of middle school students with 11-14 age group as digital game addicts.

\subsection{Sample of Research}

The sample is a limited part of the selected from the studied thread to gather information about its properties; sampling defines the process of choosing appropriate examples to represent and predict the properties of the universe and all the processes performed in this process (Büyüköztürk et al., 2016, p.81).

In this research, "purposeful sampling" and "criterion sampling" methods were used as sample selection. Purposive sampling methods are used to make use of the "homogeneous sampling" method. Homogeneous sampling method; an homogeneous subgroup of the problem of researching in the environment defines the choice of the situation to be done here (Büyüköztürk et al., 2016, p.91). The basic understanding of the criteria sampling method is the study of all situations that meet a set of predetermined criteria. The criteria or criteria mentioned here can be created by the researcher or a previously prepared list of criteria can be used (Yıldırım\&Şimşek, 2013, p.140).

Within this scope there are a total of 291 (5.6.7.8) students in the Kiz1lcahamam Imam Hatip Secondary School located in the province of Kizılcahamam in Ankara, 147 girls and 144 boys studying in the 2015-2016 education period. In this sample group, 80 (fifth, sixth, seventh, eighth) students are composed of 29 girls and 51 boys with high addiction according to the criterion sampling method. In the control and experimental groups, the obtained data were analyzed in the SPSS 20 package program and 80 students with high addiction level (total score of 49 and above) were included in the study. The selected sample group was divided into two groups as experiment $(n=40)$ and control group $(n=40)$ according to the unbiased assignment method, according to their scores, age, sex and class level.

\subsection{Data Collection Tool and Personal Information Form}

The "Digital Game Addiction Scale for Children" developed by the Hazar \& Hazar was used together with the 6-item personal information form.

When the personal information form was created, a literature search was conducted to find out what the independent variables considered to be related to digital game addiction were and the personal information form for variables such as age, gender, daily average playing time of digital game was created. The relationship between each variable and the total addiction scores from the scale was considered in the study.

The "digital game addiction scale for children" used in the research consists of four sub-factors. The Cronbach Alpha coefficients of the sub factors were found to be .75 for the first sub-factor, .80 for the second sub-factor, .72 for the third sub-factor, .56 for the fourth sub-factor and .88 for the total sub-factor. A 5-point Likert-type scale was used in evaluating the expressions in the measure $(1=$ Never, $2=$ Not agreeable, $3=$ Undecided, $4=$ Agree, $5=$ Completely agree). Factors; Excessive Focus and Conflict on Playing Digital Game, Tolerance Development in Game Play and Value Added to Game, Postponement of Individual and Social Duties / Assignments, Psychological-Physiological Reflection of Dysnity and Diving in Game.

\subsection{Collection of Data}

During the collection of data; the pre-test applied to the students was also accepted as the criterion sampling. (The students with the total score of 49 points and above were determined and the control and experimental groups were formed with the unbiased assignment method). After the 12-week training period, the data obtained by collecting the post-test data from the control and experimental groups were evaluated in the SPSS 20 package program.

\subsection{Analysis of Data}

The data obtained for the subproblems generated in the context of the overall objective were subjected to statistical analysis in the SPSS 20 packet program. It was tested by the Shapiro - Wilk test that the scores obtained were normal distributions. For this purpose, necessary statistics are processed. The parametric (t-Test, One-Way ANOVA Test) tests were used in the analysis of data when the distribution at the total scale and scale sub-dimensions fulfilled the normality assumption. Nonparametric tests (Mann-Whitney U Test, Wilcoxon Marked-Rank Test, Kruskal Wallis Test) were used in the analysis of the data when the distribution did not meet the normality assumption. Taking into account the number of independent variables in the study, the statistical operations performed were calculated on the scale total score. 


\section{Results}

In this part of the study, the information on the difference analysis of the variables belonging to the control and experiment groups is given.

Table 1 shows the data obtained regarding pre-test point differences for control and experimental groups.

Table 1. Results of the Mann-Whitney U Test on the Difference of Scale Total Points of Pre-Test Scores of Control and Experiment Groups

\begin{tabular}{lllllll}
\hline Measurement & Group & N & Mean Rank & Sum of Rank & U & p \\
\hline \multirow{2}{*}{ Pre-Test: Scale Total Score } & Control group & 40 & 42,11 & 1684,50 & \multirow{2}{*}{735,50} & \multirow{2}{*}{0,53} \\
\cline { 2 - 5 } & Experimental group & 40 & 38,89 & 1555,50 & &
\end{tabular}

As a result of the analyzes made; there was no statistically significant difference between pre-test total scores of the experimental and control group students $(U=735,500 ; p=0,53>0,05)$. According to these results there is no significant difference between the pre-test scores of the control and experimental groups and therefore the control and experiment groups have similar characteristics.

Does the experiment group's pre-test / post-test scores of digital game addiction level differ? Findings obtained for the question are given in Table 2.

Table 2. Wilcoxon Signed-Rank Test Results for Determining the Total Score Differences of the Pre-Test / Post-Test Scale for the Experiment Group

\begin{tabular}{|c|c|c|c|c|c|c|c|}
\hline Group & Measurement & Post Test - Pre Test & $\mathbf{N}$ & Mean Rank & Sum of Rank & $\mathbf{Z}$ & p \\
\hline \multirow{3}{*}{ Experimental group } & \multirow{3}{*}{ Total Score of Scale } & Negative Rank & 33 & 21,76 & 718,00 & \multirow{3}{*}{$-4,57 *$} & \multirow{3}{*}{0,00} \\
\hline & & Pozitive Rank & 6 & 10,33 & 62,00 & & \\
\hline & & Ties & 1 & - & - & & \\
\hline
\end{tabular}

According to the analysis results; for the total score of pre-test / post-test score difference of the experimental group students; $\mathrm{z}=-4,578 ; \mathrm{p}=0.00<0.05$. When the rank order and sum of the difference scores are taken into account, this difference seems to be favoring the pre-test score. These results; it shows that the addiction is decreasing.

Do the pre-test / post-test scores of the control group differ from the digital game addiction level? Findings obtained for the question are given in table 3 .

Table 3. Wilcoxon Signed-Ranks Test Results to Determine Pre-Test / Post-Test Score Differences for Total Score for Control Group

\begin{tabular}{|c|c|c|c|c|c|c|c|}
\hline Group & Measurement & Post Test - Pre Test & $\mathbf{N}$ & Mean Rank & Sum of Rank & $\mathbf{Z}$ & p \\
\hline \multirow{3}{*}{ Control Group } & \multirow{3}{*}{ Total Score of Scale } & Negative Rank & 9 & 8,72 & 78,50 & \multirow{3}{*}{$-4,23^{*}$} & \multirow{3}{*}{0,00} \\
\hline & & Pozitive Rank & 29 & 22,84 & 662,50 & & \\
\hline & & Ties & 2 & - & - & & \\
\hline
\end{tabular}

As a result of the analyzes made; total score of pre-test / post-test score differences of control group students; $\mathrm{z}=-4,236$; $\mathrm{p}=0.00<0.05$. When the rank order and sum of the difference scores are taken into account, this difference seems to favor the post-test score. According to these results; it appears that the addiction increases in the analyzes.

Does the digital game addiction level post-test scores of the control and experimental groups differ? Findings for the question given in Table 4.

Table 4. Mann-Whitney U Test Results to Determine the Post-Test Score Differences of Control and Experiment Groups

\begin{tabular}{llllllr}
\hline Measurement & Group & N & Mean Rank & Sum of Rank & U & p \\
\hline \multirow{2}{*}{ Post Test: Total Score of Scale } & Control Group & 40 & 57,02 & 2281,00 & \multirow{2}{*}{139,00} & 0,00 \\
\cline { 2 - 5 } & Experiment Group & 40 & 23,98 & 959,00 & & \\
\hline
\end{tabular}

According to the analysis results; Experiment and Control group students' post-test score differences Total score; $\mathrm{U}=$ 139,$000 ; p=0.00<0.05$ was found. When the mean rank is taken into consideration, the average of the post-test total score of the control group is higher than the average of the post-test total score of the exmeriment group. According to these results, if the post-test scores are taken into consideration, the level of addiction of the control group is significantly higher than that of the experimental group.

In this part of the study, the differences in the post-test scores of the experimental group were examined in terms of gender and age variables. The pre-test / post-test score differences for the game duration variable were examined in terms of control and experimental groups.

Does the pre-test / post-test scores of the students in the experimental group differ according to the sex? Findings for the question given in Table 5. 
Table 5. T-Test Results to Determine the Difference in Total Score Related to the Sex of the Experiment Group

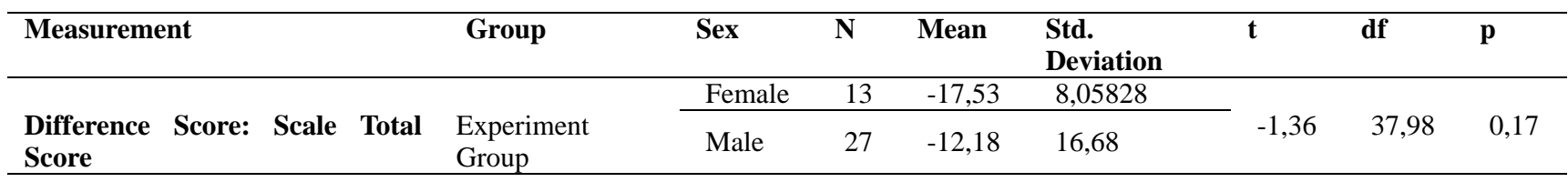

According to the analysis results; the difference score according to sex is for total score; $\mathrm{t}(37,980)=-1,368 ; \mathrm{p}=0.17>$ 0.05 .

Does the post-test scores of students' digital game addiction levels differ according to age? Findings for the question are given in Table 6.

Table 6. Kruskal Wallis Test Results of Difference Score on the Total Variable of the Age Variable

\begin{tabular}{|c|c|c|c|c|c|c|}
\hline Measurement & Age & $\mathbf{N}$ & Mean Rank & df & $\chi^{2}$ & p \\
\hline \multirow{4}{*}{ Difference Score: Scale Total Score } & 11 & 6 & 22,25 & \multirow{4}{*}{3} & \multirow{4}{*}{5,54} & \multirow{4}{*}{0,13} \\
\hline & 12 & 15 & 15,90 & & & \\
\hline & 13 & 10 & 20,20 & & & \\
\hline & 14 & 9 & 27,33 & & & \\
\hline
\end{tabular}

There was no statistically significant difference $(\mathrm{p}<0.05)$ between the total score and the age variable $(\chi 2(\mathrm{sd}=3, \mathrm{n}=$ 40) $=5,546, \mathrm{p}=0,13>0,05$.

Does pre-test / post-test scores of the students' levels of digital game addiction differ according to playing time? Findings for the question are given in Tables 7, 8, 9 and 10. Chi-square analysis was used in the analyzes. If the used method is less than 20 percent of the theoretical frequencies calculated for each cell (cell), the Pearson chi-square test, if greater than 20, is used. Tables regarding the data obtained according to pre-test and post-test measurement scores regarding the playing time of the Control and Experiment groups are given in percentages.

Table 7. Experiment and Control Groups Game Playing Time Pre-Test Measurements

\begin{tabular}{|c|c|c|c|c|}
\hline & & $\begin{array}{l}\text { Group } \\
\text { Contr } \\
\end{array}$ & $\overline{\text { Control GroupExperiment Group }}$ & Total \\
\hline \multirow{8}{*}{ Daily Average Game Playing Time Pre-test } & \multirow{2}{*}{$30-60 \mathrm{~min}$} & Frequency8 & 4 & 12 \\
\hline & & Percent 20,0 & 10,0 & 15,0 \\
\hline & \multirow{2}{*}{$61-90 \mathrm{~min}$} & Frequency10 & 9 & 19 \\
\hline & & Percent 25,0 & 22,5 & 23,8 \\
\hline & \multirow{2}{*}{$91-120 \mathrm{~min}$} & Frequency 15 & 19 & 34 \\
\hline & & Percent 37,5 & 47,5 & 42,5 \\
\hline & \multirow{2}{*}{$121 \mathrm{~min}$. and ove } & Frequency 7 & 8 & 15 \\
\hline & & Percent 17,5 & 20,0 & 18,8 \\
\hline \multirow{2}{*}{ Total } & & Frequency 40 & 40 & 80 \\
\hline & & $\begin{array}{ll}\text { Percent } 100,0 \\
\end{array}$ & 100,0 & 100,0 \\
\hline
\end{tabular}

According to the results of the analysis there was no statistically significant relation between Pre-test measures and Group Daily Game Playing Time, $\chi^{2}(\mathrm{sd}=3, \mathrm{n}=80)=1,923 ; \mathrm{p}=0,58>0,05$, (sd: degrees of freedom). Playing time of the control and experimental groups did not differ significantly from pre-test measures.

Table 8. Comparison of Playtime Pre-Test / Post-Test Measurements for the Control Group

\begin{tabular}{|c|c|c|c|c|}
\hline & & $\begin{array}{l}\text { Cont } \\
\text { Pre-t }\end{array}$ & t Grou & Total \\
\hline \multirow{8}{*}{ Daily Average Game Playing Time } & \multirow{2}{*}{$30-60 \mathrm{~min}$} & Frequency 8 & 6 & 14 \\
\hline & & Percent 20,0 & 15,0 & 17,5 \\
\hline & \multirow{2}{*}{$61-90 \mathrm{~min}$} & Frequency 10 & 6 & 16 \\
\hline & & Percent 25,0 & 15,0 & 20,0 \\
\hline & \multirow{2}{*}{$91-120 \mathrm{~min}$} & Frequency 15 & 19 & 34 \\
\hline & & Percent 37,5 & 47,5 & 42,5 \\
\hline & \multicolumn{2}{|c|}{121 min. and over Frequency 7} & 9 & 16 \\
\hline & 121 & $\mathrm{r}$ Percent & 22,5 & 20,0 \\
\hline \multirow{2}{*}{ Total } & & Frequency40 & 40 & 80 \\
\hline & & Percent & 100,0 & 100,0 \\
\hline
\end{tabular}

According to the analysis results; there was no statistically significant relationship between the pre-test and post-test measures of the control group's daily average playing time, $\chi 2(s d=3, n=80)=2,006 ; p=0.57>0.05)$. There was no difference in the daily playing time of the Control Group. 
Table 9. Comparison of Playtime Pre-Test / Post-Test Measurements for the Experiment Group

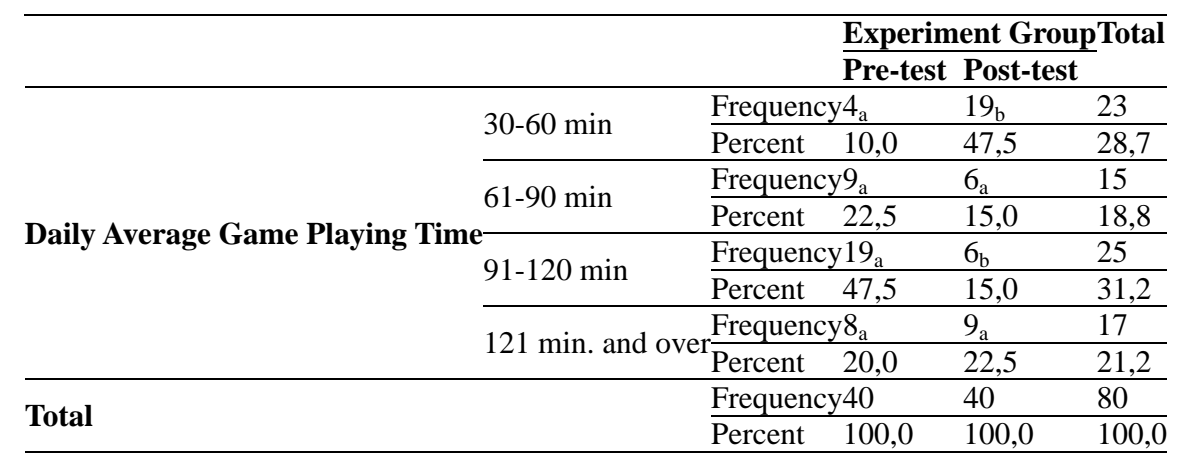

** $a, b, c$ : Indicates group differences. There is no difference in the groups in which the same letters appear. (Variants that have no difference are not alphabetic.)

According to the results of the analysis, there is a statistically significant relationship between pre-test and post-test measures of daily play time of the experimental group, $\chi 2(\mathrm{sd}=3, \mathrm{n}=80)=17,201 ; \mathrm{p}=0.00<0.05$, $)$.

The playing time is $30-60 \mathrm{~min}$. (10.0\%) are lower than the pre-test ratios $(47.5 \%)$ during the game. According to this result, there was a decrease in the playing time of the students after the change.

The playing time is $91-120 \mathrm{~min}$. (47.5\%) is higher than the pre-test rate $(15.0 \%)$. According to this result, there was a decrease in the playing time of the students after the change.

Table 10. Experiment and Control Groups Game Playing Time Post-Test Measurements

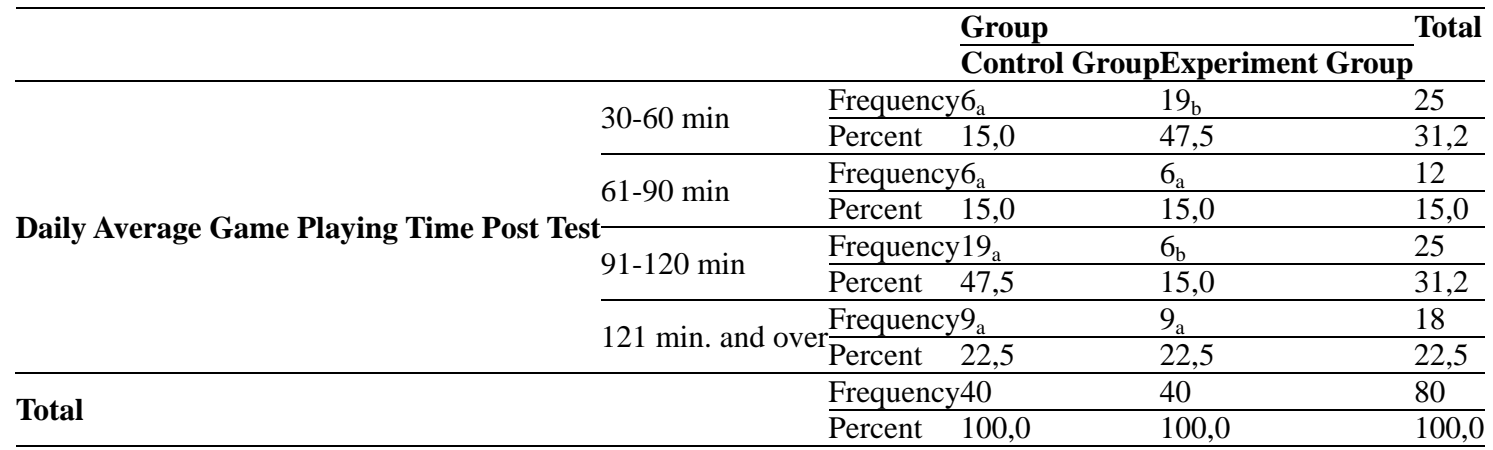

** $a, b, c$ : Indicates group differences. There is no difference in the groups in which the same letters appear. (Variants that have no difference are not alphabetic.)

According to the analysis results, there is a statistically significant relationship between control and experimental groups according to the game time post-test scores, $\chi 2(\mathrm{sd}=3, \mathrm{n}=80)=13,520 ; \mathrm{p}=0,00<0,05$, ) Playing time 30-60 min. the proportion of the experimental group (47.5\%) was higher than that of the control group (15.0\%). According to this result, the proportion of the students in the experimental group, which is 30-60 minutes (the lowest playing period), increased significantly compared to the control group. The playing time is $91-120 \mathrm{~min}$. (15.0\%) were lower than the control group (47.5\%). According to this result, the proportion of the students in the experimental period, which is 91-120 minutes (high game playing time), decreased significantly compared to the control group.

\section{Discussion and Conclusion}

In this research, the effectiveness of physical activities games on the game addiction. It has been investigated whether the experimental group's digital game addiction level pre-test scores differed from post-test scores. According to the analysis results (Table 2); it was observed that the pre-test / post-test score differences of the experimental group differed significantly for the total score. This observed difference seems to favor the pre-test score. According to these results, the level of digital game dependency of the experimental group of the experimental group is decreased after the applied program.

Scientists researching digital game addiction have various therapy methods that they suggest in the solution of this problem. The most prominent of these methods are: cognitive-behavioral therapy, motivational interviews, family therapy, solution-focused therapy and writing-narrative therapy, and sports-exercise is seen as an important component in almost all of these therapies (Kim et al., 2013; Lee, 2014, Pallesen et al. 2016). Öztürk et al. (2007) stated that, as one of the treatment methods of internet addiction in the study "Internet addiction: clinic and treatment", it is necessary that individuals should be directed to activities that reduce the time spent on the internet and that sports activities will give 
effective results at the beginning of these activities. Park et al. (2016), "The effects of virtual-reality therapy for online gaming addiction therapy"; Twenty-four adult males aged 18 years or older who were in the psychiatry department of Chung-Ang University who were in the game addiction treatment participated in the research. Participants were divided into groups of 12 persons as cognitive-behavioral therapy group (control group) and virtual reality therapy group (experimental group), and therapies were applied to these groups for four weeks. According to the results of the study, as a result of four weeks of application; the addiction scores of both the cognitive-behavioral therapy group (control) and the virtual-reality therapy group (experiment) decreased significantly. Landade and Roderick (2014), "Potential Role of Sports in Addiction Therapy" They conducted interviews with individuals who participated in a life-course project called "Second Chance" under the framework of alcohol and substance addiction in the UK and investigated the contribution of this course to the struggle of individuals in addiction. In the interviews, the participants emphasized the socialization of the sport and stated that family relationships were improved, friendships, relieved from annoyance and started to take alternative activities so that alcohol and substance use thought and behavior began to move away from their lives. They also emphasized that they feel mentally and physically better and that their self-efficacy is increased by sports.

As a result of the analysis of whether the control group's pre-test scores of digital game addiction level differ from post-test scores (Table 3); test group scores of the control group increased significantly in favor of the post-test for the scale total score. According to these results; the level of addiction of the control group increased. It may be considered that the students in the control group lacking physical mobility games which could be an alternative to digital games may be an important factor in increasing the level of digital game play behavior and addiction of these students. In the literature, with the development of technology, especially children's playing habits gradually change and children are increasingly concentrating on digital games with each passing day. For example; According to Kaya (2013), human life has become virtual in many areas, and one of these areas is games. Today, instead of playing on the streets or on the sporting grounds, children play with their friends at home, in internet cafes or play-station halls. According to Kars (2010), the technology that changed many habits in human life changed the habits of children to play and it became a habit of playing digital games without evaluating the leisure time of children. According to Karayağız-Muslu and Bolışı (2009), it leads to a decrease in energy consumption, causing more time spent in computer, less children playing games, doing sports less time. Davis (2001) stated that while cognitive-behavioral therapy developed for internet addiction therapy requires that the duration of internet use of dependent individuals be reduced and that individuals should be directed towards various exercise activities as an alternative activity during this period, exercise is seen as an important component of addiction treatment.

As a result of the analysis of whether the control and experimental groups' digital game addiction level post-test scores differed (Table 4); the post-test total scores were found to be significantly higher in favor of the Control group. As a result of the changes made according to these results, the level of digital game addiction of the experimental group decreased while the level of digital game addiction of the control group without change increased. Therefore, it can be said that games with physical mobility are an important tool in lowering the level of digital game addiction. Although not related to digital gaming addiction in the literature, there are studies and opinions that sport, substance addiction and behavior addiction are an important tool used in the treatment process and in the post-treatment period. Yeltepe Ercan (2013) has made one of the studies that can be considered as an example of the use of sports in addiction treatment. In a study on "investigating the effects of depression, anxiety and quality of life on the patients who have participated in regular exercise", 34 participants were treated with 4 weeks of exercise program and exercises were made in the experimental group for 3 days and 20-60 minutes per week. The control group continued his routine life. As a result of the research, it was observed that the level of anxiety decreased and the level of quality of life increased in the experimental group, and the experimental group had lower depression score than the control group. However, there was no change in the scores of the control group. These results show that exercise-sport may be an effective method for combating addiction. However, the results of study on the level of spore participation and research on the relationship between internet and computer game addiction of high school students in Hazar, Mamak and Çınar (2015) and some variables do not coincide with the opinions in the field. According to the results of the research, the students who have athletic license have a higher level of digital game addiction than those who do not have a sportsman license and the result is that daily sports making variable does not affect the addiction level.

As a result of the analysis of whether the pre-test / post-test scores of the students of the experimental group differ according to the sex (Table 5). The difference score according to sex is not significantly different for the scale total score. These results; the gender variable has no effect on the level of digital game addiction. Factors such as diversity in digital gaming and the availability of appropriate game genres of every genre and the development of technology, as well as the fact that not only men but also girls are easily accessible to digital gaming vehicles can be important reasons for this research result as the main reason of this research result. For example; Gentile and Anderson (2006) state that children spend considerably more on video games in the last thirty years, this is an important reason why more 1980 
games have been played in atari halls with the development of technology. The predecessors indicate that these games, which boys can play, can now easily and frequently be played by girls. In another exemplary study, Blinka and Mikuška (2014), "The role of social motivation and socialization in online gaming addiction" it was seen that there was no significant difference in terms of sex change among the daily-casual gamers, daily high-level gamers, and at-risk dependent groups. However, in the field, researches that reach the conclusions in the direction of these opinions are majority. For example; Horzum (2011) concluded that the addiction level of male students was significantly higher than that of female students in the study titled "Examination of computer game addiction levels of primary school students according to various variables". In another study; Kneer et al. (2014), a study in which individuals address risk factors that drive problem-solving behavior; sex variable is an important variable and male adolescents can be more easily affected than girls. Akçay and Özcebe (2012) point out that male students play significantly more computer games (digital games) than girls in their study of "Assessing the Playing Habits of Children and Their Families".

As a result of the analyzes regarding whether the pre-test / post-test scores of the students in the experiment group differ according to age (Table 6); No significant difference was found for the total score. According to these results, it is determined that there is no relation between digital game dependency and age. Considering that digital games are designed specifically for children and young people, designing games that appeal to all age groups, in particular, can be the reason why there is no difference between the levels of gaming addiction according to age of children participating in the research. However, when the literature is examined in the literature, it is seen that there are researches that have reached the findings in the opposite direction of these results. Kale and Erşen (2003) state that children start to move away from their families during adolescence, establish strong ties with their group of friends, and build these ties on certain values. Knee et al. (2014), the age variable is an important factor in digital games. However, adolescents tend to play games rather than adults by disrupting their individual and social duties. In a study paralleling this research, In another study Festl, Scharkow \& Quandt (2016), in the study "Playing computer games with problems in adolescents, teenagers and adults"; 580 adolescents in the age range 14-18, 1866 young adults in the 19-39 age range, and 1936 adults over the age of 40 were included in the study. According to the results of the research, there is an inversely proportional relationship between the level of video game addiction and age, and it is the result of young people playing video games for a longer time. Donati et al. Concluded that age is a relation with addiction. (2015), "Diversity and dependence in games: Male teenagers, video game variety and dependency relationship"; 701 male teenagers aged 13-18 years included in the survey. According to the results of the research, there is no relation between age-variable video game variety and video game addiction.

As a result of the analysis of whether the pre-test / post-test scores of the students in the Experiment and Control group differ according to the digital playing time (Table 7-8-9-10); There is no statistically significant relationship between the pre-test and post-test measures of the average daily playing time of the control group. According to the results of the analysis, there is a statistically significant relationship between pre-test and post-test measurements of the daily playing time of the experimental group, the playing time is 30-60 min. (10.0\%) are lower than the post-test post-test ratios $(47.5 \%)$. The playing time is $91-120$ min. pre-test ratios $(47.5 \%)$ are higher than the post-test post-test ratios (15.0\%).According to the results of the analysis, there is a statistically significant difference between the control and experimental groups according to the game time post-test scores, the playing time is $30-60 \mathrm{~min}$. the proportion of the experimental group (47.5\%) was higher than that of the control group (15.0\%). The playing time is $91-120 \mathrm{~min}$. $(15.0 \%)$ were lower than the control group (47.5\%). According to the analysis results; there is no difference between pre-test scores of daily digital game play times of the selected experimental and control groups. After 12 weeks of training, the experimental group's daily playing time of digital games decreased. This differentiation is 30-60 min. with 91-120 min. Time 30-60 min. while the number of people playing the game increased after training, 91-120 min. the number of people with playing time decreased, 61-90 min. and $121 \mathrm{~min}$. and there have not been any changes in the numbers of players who play with it. There is no change in the daily game play time of the control group. According to these results; it was seen that the control group did not show a statistically significant change in the daily digital playing time but significantly decreased the playing time of the experimental group. Therefore, it can be said that the games with physical mobility decrease the level of daily digital gaming by the students in the experiment group and this decrease is effective in decreasing the level of digital game addiction. There are many researches that show a linear relationship between the duration of digital gaming and gaming addiction. For example; Irles and Gomis (2015) have investigated "Impulsivity and video game addiction"; 411 adolescents aged 12-16 years examined the relationship between "impulsivity level" and "video game addiction". According to the results of the research; there is a significant positive correlation between duration and frequency of attendance at computer and video addiction level. A similar study by Festl et al. (2016), in the study "Playing computer games with problems in adolescents, teenagers and adults"; 580 adolescents in the age group 14-18, 1866 young adults in the age group 19-39 and 1936 adults over the age of 40 were included in the study. According to the results of the research; there was a significant and high correlation between the duration of daily gaming and the video game addiction level. Gökçearslan and Durakoğlu (2014), who conducted a 
similar research, "have examined the computer game addiction levels of secondary school students according to various variables. According to the results of the research; the level of addiction of those who play more than 3 hours a day computer game (digital game) is higher than those who play up to 1 hour a day, while those who play several times a week are higher than those who play once a week.

Also within the scope of this research; participants in the control and experimental groups also examined the levels of "digital game addiction according to parents' education levels". As a result of the statistical procedures performed, it was concluded that parents' education levels of the participants in the control and experimental groups did not affect the digital game addiction statistically significantly.

\subsection{Finally}

As a result; it has been achieved that the levels of digital game addiction decreased significantly with the advent of games with physical activity in the free time of the students who are addicted to digital games and sports. Therefore, it can be said that games with physical mobility are important method in reducing the level of digital game dependency.

Recommendations for research results:

The scope of this research is limited only to middle school students. In subsequent periods, similar studies may be performed on all stages of formal education and in different age groups, which may be useful for achieving more general results. In similar studies to be done, scientific studies should be done at the point of solution of the problem by taking a broader view of the issue from an interdisciplinary point of view (Physical Education, PDR, Medicine, etc.). The use of the qualitative research model in the new researches to be investigated and the reasons for pushing the individuals to digital game addiction will be useful in the context of cause-effect relationship.

\section{References}

Akçay, D., \& Özcebe, H. (2012). Evaluation of Computer Game Playing Habits of Children at Pre-School Education Levels and Their Families. Journal of Child, 12(2), 66-71. https://doi.org/10.5222/j.child.2012.066

Akçayır, G. (2013). Health effects of digital games. Ankara: Pegem Akademi.

Arslan, E., Bütün, P., Doğan, M., Dă̆, H., Serdarzade, C., \& Arıca, V. (2014). Computer and internet usage in childhood. İzmir Dr. Journal of Behçet Uz Child Hospital, 4(3), 195-201.

Binark, M., Bayraktutan-Sütçü, G., \& Fidaner, I. B. (2009). Digital game guide "game design genres and player". İstanbul: Kalkedon.

Blinka, L., \& Mikuška, J. (2014). The role of social motivation and sociability of gamers in online game addiction. Cyberpsychology: Journal of Psychosocial Research on Cyberspace, 8(2), 1-6. https://doi.org/10.5817/CP2014-2-6

Burak, Y., \& Ahmetoğlu, E. (2015). Study of Effects of Computer Games on Aggression Level of Children. International Periodical for the Languages, Literature and History of Turkish or Turkic, 10(11), 363-382.

Büyüköztürk, Ş., Kılıç Çakmak, E., Akgün, Ö. E., Karadeniz, Ş., \& Demirel, F. (2016). Scientific research methods. Ankara: Pegem Akademi.

Davis, R. A. (2001). A cognitive-behavioral model of pathological Internet use.Computers in Human Behavior, 17(2), 187-195. https://doi.org/10.1016/S0747-5632(00)00041-8

Demirtaş-Madran, H. A., \& Ferligül-Çakılcı, E. (2014). The relationship between agression and online video game addiction: a study on massively multiplayer online video game players. Anatolian Journal of Psychiatry, 15(2), 99-107. https://doi.org/10.5455/apd.39828

Dolu, O., Büker, H., \& Uludağ, Ş. (2010). Effects of Violent Video Games on Children. An Assesment on Agression Violence and Delinquency. Thurkish Journal of Forensic Sciences, 9(4), 54-75.

Donati, A. M., Chiesi, F., Ammannato, G., \& Primi, C. (2015). Versatility and addiction in gaming: the number of video-game genres played is associated with pathological gaming in male adolescents. Cyberpsychology, Behavior, and Social Networking, 18(2), 275-289. https://doi.org/10.1089/cyber.2014.0342

Erboy, E. (2010). The Factors Which Effect on Computer Game Addiction of 4th and 5th Grade Primary Students. Master Thesis, Adnan Menderes University Institute of Social Sciences, Aydın.

Erkuş, A. (2013). Scientific research process for behavioral sciences. Ankara: Seçkin.

Festl, R., Scharkow, M., \& Quandt, T. (2016). Problematic computer game use among adolescents, younger and older adults. Addiction, 108(3), 592-599. https://doi.org/10.1111/add.12016 
Gentile, D. A., \& Anderson, C. A. (2006). Video games. Encyclopedia of Human Development, 3(8), 1303-1307.

Gökçearslan, Ş., \& Durakoğlu, A. (2014). An Analysis of Video Game Addiction Levels Among Secondary School Students According to Several Variables. Dicle University Journal of Ziya Gökalp Faculti of Education, 23(14), 419-435.

Griffiths, M. D. (2009). Online computer gaming: Advice for parents and teachers. Education and Health, 1(27), 3-6.

Hazar, Z., \& Hazar, M. (2017). Digital Game Addiction Scale for Children. Journal of Human Sciences, 14(1), 203-216. https://doi.org/10.14687/jhs.v14i1.4387

Horzum, M. B. (2011). Examining Computer Game Addiction Level of Primary School Students in Terms of Different Variables . Education and Science, 36(159), 57-68.

Horzum, M. B., Ayas, T., \& Çakırbalta, Ö. (2008). Computer Game Addiction Scale For Children. Turkish Psychological Counseling and Guidance Journal, 3(30), 76-88.

Irles, D. L., \& Gomis, R. M. (2015). Impulsiveness and Video Game Addiction. Health and Addictions. ISSN 1578-5319. ISSNe 1988-205X, 16(1), 33-40.

Kale, R., \& Erşen, E. (2003). Introduction to physical education and sports science. Ankara: Nobel.

Karayağız-Muslu, G., \& Bolışık, B. (2009). Internet Usage Among Children and Young People. TAF Prev. Med. Bull, $8(5), 445-450$.

Kars, G. B. (2010). The Effect of Violence Computer Games on The Attitude in Children. Master Thesis, Ankara University Institute of Health Sciences, Ankara.

Kaya, B. A. (2013). Development of Online Game Addiction Scale: A Scale Valıdity and Reliability Study. Master Thesis, Gaziosmanpaşa University Institute of Educational Sciences, Tokat.

Kim, P. W., Kim, S. Y., Shim, M., Im, C., \& Shon, Y. (2013). The influence of an educational course on language expression and treatment of gaming addiction for massive multiplayer online role-playing game (MMORPG) players. Computers \& Education, 63(5), 208-217. https://doi.org/10.1016/j.compedu.2012.12.008

Kneer, J., Rieger, D., Ivory, J. D., \& Ferguson, C. (2014). Awareness of Risk factors for digital game addiction: Interviewing players and counselors. Int. Journal of Ment. Health Addiction, 12(8), 585-599. https://doi.org/10.1007/s11469-014-9489-y

Landade, S., \& Roderisk, M. (2014). Recovery from addiction and the potential role of sport: Using a life-course theory to study change. International Review for the Sociology of Sport, 49(3/4), 468-484. https://doi.org/10.1177/1012690213507273

Lee, E. J. (2011). A case study of internet game addiction. Journal of Addictions Nursing, 22(3), 208-213. https://doi.org/10.1080/07380560903360178

Lieberman, D. A., Fisk, M. C., \& Biely, E. (2009). Digital games for young children ages three to six: from research to design. Computers in the Schools, 26(3), 299-313. https://doi.org/10.3109/10884602.2011.616609

Müller, K. W., Janikian, M., Dreier, M., Wölfling, K., Beutel, M. E., Tzavara, C., Richardson, C., \& Tsitsika, A. (2014). Regular gaming behavior and internet gaming disorder in European adolescents: results from a cross-national representative survey of prevalence, predictors and psychopathological correlates. Eur. Child Adolesc. Psychiatry, 24(3), 565-574.

Ögel, K. (2012). Internet bağımlılığı- internetin psikolojisini anlamak ve bağımlılıkla başa çıkmak. İstanbul: Türkiye İş Bankası Kültür.

Öztürk, D. (2007). Investigation of the effects of computer games on cognitive and affective development of children. Master Thesis, Dokuz Eylül University Institute of Educational Sciences, Izmir.

Öztürk, Ö., Odabaşığlu, G., Eraslan, D., Genç, Y., \& Kalyoncu, A. (2007). Internet addiction: clinical aspects and treatment strategies. Journal of Dependence, 8(13), 36-41.

Pallesen, S., Lorvik, I. M., Bu, E. H., \& Molde, H. (2015). An exploratory study investigating the effects of a treatment manual for video game addiction. Psychological Reports: Mental \& Physical Healt, 117(2), 490-495. https://doi.org/10.2466/02.PR0.117c14z9

Park, S. Y., Kim, S. M., Roh, S., Soh, M. A., Leed, S. H., Kim, H., Lee, Y. S., \& Hana, D. H. (2016). The effects of a virtual reality treatment program for online gaming addiction. Computer Methods and Programs in Biomedicinec, 129(9), 99-108. https://doi.org/10.1016/j.cmpb.2016.01.015 
Şahin, C., \& Tuğrul, M. (2012). Defining The Levels of Computer Game Addiction of The Primary School Students. Zeitschrift für die Welt der Türken-Journal of World of Turks, 4(3), 15-30.

Smith, G. (2004). How do computer games affect your children?. Eurasian Journal of Educational Research (EJER), 17(9), 72-80.

Tarhan, N., \& Nurmedov, S. (2011). Addiction - virtual or real. İstanbul: Timaş.

Yeltepe-Ercan, H. (2013). Exercise therapy in the treatment of addiction. Ankara: Nobel.

Yengin, D. (2010). Violence in digital games - new violence. Ph.D. Thesis, Marmara University Institute of Health Sciences, Istanbul.

Young, K. S. (2004). Internet addiction: A new clinical phenomenon and its consequences. American Behavioral Scientist, 48(4), 402-415. https://doi.org/10.1177/0002764204270278

\section{Copyrights}

Copyright for this article is retained by the author(s), with first publication rights granted to the journal.

This is an open-access article distributed under the terms and conditions of the Creative Commons Attribution license which permits unrestricted use, distribution, and reproduction in any medium, provided the original work is properly cited. 